\title{
Pengaruh Teologi Terhadap Perbuatan Dan Sikap Hidup Manusia
}

Basori

Dosen Fakultas Tarbiyah UIIS Malang

\begin{abstract}
In Islamic studies, theology is put in a central position as it not only clarifies the basic Islam concepts, but also has a significant role in determining Moslem attitude. The great advanced of Moslem civilization among other, was supporied by the strong influence of rational theology initiated by Mutazillah. For this reason, Nasution believes that civilization of Moslem world is determined by the theology thought they believe. If modern people believe in a rational way of life, then, traditional theology becomes a significant pre- requisite.
\end{abstract}

\section{A. Pengantar}

Islam telah membuka diri dalam kajian ilmiah, baik dari syari' ah ${ }^{1}$ maupun makidah. ${ }^{2}$ Syari'ah mempunyai garapan aplikatif (amal al salihah) ${ }^{3}$ yang terkemas dalam ibadah. ${ }^{4}$ Kemudian dalam perkembangannya ibadah menjadi sebuah disiplin ilmu yang dikenal dengan nama fiqh.' Sedangkan akidah menggarap aspek teoritis (nazary) yang dikemas dalam al iman (kepercayaan). 
Dari kedua aspek di atas (akidah dan syari'ah) telah dijelaskan oleh wahyu Allah, baik al-Qur'an maupun al Hadits, melalui Nabi Muhammad SAW. Ternyata Nabi Muhammad SAW itu lebih senang menggarap akidah (ciri-ciri ayat Makkiyah) ${ }^{6}$ dan mengemudiankan syari'ah. Akidah senantiasa berkembang dan menjadi kajian intelektual Islam yang tergabung dalam wadah mutakallimin Mutakallimin (teologi Islam) membahas akidah yang bersumber dari syahadah secara panjang lebar yang kemudian melahirkan beberapa aliran teologi Islam secara komprehensip.?

Dalam relaitas hidup antara akidah dan syari'ah tidak dapat dipisahkan. Keduanya mempunyai obyek kajian yang berbeda, satu sisi bersifat teoritis, akan tetapi satu dengan yang lain saling menunjang. Dari segi praktisnya umat Islam telah melaksanakan ibadah, baik shalat, puasa, haji, sedekah, jihad, dan beberapa amal salih lainnya. Dari segi teoritis ada beberapa metode berpikir teologi yang dapat dikelompokkan dalam dua kategori besar, yaitu metode berpikir Qadariyah dan Jabbariyah.

Dalam makalah ini akan dibahas lebih mendalam tentang Pengaruh Teologi Terhadap Perbuatan Dan Sikap Hidup Manusia, baik Qadariyah maupun Jabariyah. Sebenarnya yang menjadi permasalahan besar adalah, tatkala pengaruh teologi tersebut sudah berbentuk tindakan maupun sikap. Hal ini akan berbenturan dengan pengaruh syari'ah. Agar tidak terjadi yang demikian, sikap dan tindakan manusia dilihat dari sisi semangatnya. Dari beberapa identifikasi masalah tersebut, penulis akan mencoba memberikan deskripsi awal yang selanjutnya dibahas dan dikembangkan lebih mendalam.

\section{B. Teologi, Sebuah Tinjauan Historis}

Teologi berasal dari bahasa Yunani "theos" dan "logos". Theos berarti Tuhan dan logos berarti ilmu atau ajaran. Teologi secara bahasa berarti ilmu atau ajaran tentang Tuhan. ${ }^{8}$ Dalam pengertian yang lebih luas dapat dikatakan teologi adalah pengetahuan tentang Tuhan, baik mengenai sifat-sifat Allah, dasar-dasar kepercayaan kepada Allah dan agama, terutama berdasarkan kepada kitab suci.9

Istilah teologi muncul dan dipakai oleh orang/agama Kristen. Orang Kristen menyebut Tuhan (trinitas) dengan salah satu sebutan Allah dengan dibaca tarhiq, ${ }^{10}$ sedangkan kaum muslimin menyebut Tuhan (Maha Esa) dengan sebutan Allah 
dibaca tafhim. ${ }^{11}$ Perkembangan teologi dalam dunia Kristen berlangsung cukup lama, sehingga muncul beberapa aliran teologi, seperti teologi natural ${ }^{12}$ teologi wahyu, ${ }^{13}$ teologi dialektika ${ }^{14}$ teologi negatif, ${ }^{15}$ dan sebagainya.

Dalam Islam munculnya teologi diawali dengan munculnya persoalanpersoalan politik, terutama mencapai puncaknya pada zaman Khalifah Ali ibn Abi Thalib dan Mu'awiyah ibn Abi Sofyan. ${ }^{16} \mathrm{Hal}$ ini senada dengan Fazlur rahman yang menganalisa agama secara kritis dan logis. Ia mengatakan sikap sederhana namun efektif dan praktis telah diajarkan oleh al-Qur'an dan al-Hadits, pertama kali terguncang kedalam refleksi karena pergolakan pada masa Khalifah Utsman ibn Affan dan Ali ibn Abi Thalib. ${ }^{17}$ Permasalahan teologi yang pertama kali muncul sekitar dosa besar dan hukum kafir bagi kaum muslimin. Untuk mensikapi permasalahan itu muncul tiga kelompok umat Islam yang menyatakan diri sebagai aliran teologi Islam, yaitu Khaw'arij, Murji 'ah dan Mu'tazilah. ${ }^{18}$

Teologi Khawarij menegaskan bahwa orang muslim yang melakukan dosa besar termasuk kafir dan kekal di neraka jika tidak bertaubat sebelum mati. Doktrin teologinya yang lain adalah "la hukma illa lillah", berarti yang berhak menetapkan hukum hanya Allah, bukan manusia. Orang yang mengikuti keputusan manusia termasuk kafir. Sebagaimana halnya orang-orang yang melakukan tahkim, seperti Abu Musa al- Asy'ari Amru ibn Ash, Ali ibn Abi Thalib, Mu'awiyahibn Abi Sofyan adalah kafir. Termasuk orang-orang yang menerima keputusan tahkim, seperti kelompok pendukung Ali dan kelompok pendukung Mu'awiyah. Juga orang-orang yang terlibat perang jamal, seperti A'isyah, Thalhah dan Zuber. ${ }^{19}$ Teologi Khawarij bersifat fanatis dan eklusif. Sifat inilah yang menjadikan bumerang bagi dirinya. Bukan sekedar dimusuhi oleh penguasa, tetapi umat Islam banyak yang menentang.

Khawarij berteologi semula berangkat dari sikap kritis mereka terhadap perilaku dan siapa yang berhak menjadi khalifah, siapa yang termasuk mukmin dan siapa pula yang termasuk kafir. Pandangan khawarij terhadap khalifah adalah demokratis. Khalifah wajib dilakukan dengan pemilihan terhadap muslim yang merdeka. Kalau seorang khalifah sudah terpilih, ia tidak boleg mengundurkan diri, khalifah tidak disyaratkan dari suku Quraisy, bahkan seorang budak boleh dipilih menjadi khalifah. ${ }^{20}$

Dari masalah khalifah kemudian berkembang kearah pembahasan iman dan amal salih. ${ }^{21}$ Pembahasan ini dimulai sejak masa pemerintahan Abd. Malik ibn Marwan. Berangkat dari obyek khalifah dan agama inilah khawarij berkembang 
menjadi beberapa kelompok, sampai ada yang mengatakan 20 kelompok. ${ }^{22} \mathrm{Di}$ antara keduapuluh itu ada tiga yang sangat terkenal, yaitu kelompok al Azarikah. ${ }^{23}$ al Nadjat, ${ }^{24}$ dan Ibadiyah. ${ }^{25}$

Di tengah tersiamya teologi khawarij yang bersifat ekstrim dan eklusif, muncullah paham teologi yang lebih lunak dan moderat dalam hal iman, kufur, dan mukmin. Orang yang berbuat dosa tetap mukmin, ${ }^{26}$ sebab amal tidak dapat mempengaruhi iman seseorang. Dan juga pelaku dosa akan menunggu keputusan sampai hari akhir dan keputusan itu ditentukan oleh Tuhan, ${ }^{27}$ apakah Tuhan akan memberikan siksa atau bahkan Tuhan akan mengampuninya. ${ }^{28}$ Komandan paham tersebut mengatasnamakan dirinya sebagai aliran Murji'ah yang terjadi pada masa Utsman ibn Affan dan Ali ibn Abi Thalib. Untuk menentukan sikap kepada keduanya, Murji'ah bersikap netral. Tradisi netralitas dan moderat dalam bidang keagamaan dan politik ini mayoritas diikuti oleh sahabat dan orang-orang Madinah. ${ }^{99}$ Etos ketaatan, amaliah dan kemoderatan benar-benar menjadikan Madinah sebagai pusat pengembangan keagamaan. Kepemimpinan mereka terasa terusik setelah mendapat pengaruh yang keras dari Bani Umayyah, padahal mereka kurang begitu suka terhadap mereka. Sikap mereka bukan memusuhi atau menjadi oposisi, tetapi justru mengalihkan perhatiannya kepada pengembangan keilmuan agama dan hadits. $^{30}$

Karena sikap lunak dan moderat, Murji' ah lambat laun tenggelam ketingkat alim, perilakunya dilatarbelakangi oleh moralitas yang taat daripada keingintahuan spekulatif. Dialah Hasan al Basri (wafat 110 H/718 M) sebagai tempat bertanya. Suatu ketika, dia ditanya tentang pertentangan antara pendapat kaum khawarij dan kaum murji'ahıtentang kedudukan orang yang berbuat dosa. Sebelum dia menjawab, terlebih dahulu dijawab oleh muridnya Wasil ibn Atha'. Peristiwa dramatis ini yang kemudian memunculkan nama Mu'tazilah. ${ }^{31}$ Dengan kendali wasil ibn Atha', mu'tazilah mengalami dua masa keemasan, yaitu masa Dinasti Abbasiyah (198-232 H) dan pada masa Dinasti Buwayah $(334-447 \mathrm{H})$, karena adanya dukungan pihak penguasa. Ajaran mu'tazilah yang terkenal adalah lima unsur doktrin, yaitu al tauhid (ke Esaan Allah), al adlu (Keadilan Allah), al Manzilah Bain al Manzilatain (tempat di antara dua tempat), al Wa'd wa al Wa'id (janji dan ancaman) dan al Amru bi al Ma'ruf wa al Nahyu an al Munkar (amar ma'ruf dan nahi munkar). ${ }^{32}$

Setelah mendapat dukungan dari penguasa, kegiatan Mu'tazilah mulai redup. Kegiatan lebih dipusatkan kepada mendirikan lembaga sekolah untuk para teolog 
intelektual yang dalam kenyataannya tidak mempunyai pengikut yang berarti. Zaman kemunduran ini adalah wajar setelah pusat posisi kaum Mu'tazilah tidak relevan lagi bagi kehidupan kontemporer dan dianggap bertentangan dengan masyarakat secara keseluruhan. Namun kondisi ini tidak sama sampai menghilangkan sumbangsih dan andil besar Mu'tazilah yang telah berhasil meletakkan dasar utama bagi teologi filsafat. ${ }^{33}$

Dengan melemahnya Mu'tazilah (karena tidak dapat dukungan dari penguasa) muncullah aliran teologi Asy'ariyah yang lahir dari tubuhnya sendiri. ${ }^{34}$ Sebagai pendiri teologi Asy'ariyah adalah Abu Musa al Asy'ari ${ }^{35}$ dan selanjutnya menyebarkan pahamnya dan banyak diikuti oleh kaum muslimin. Secara singkat pendapatnya itu adalah mengenai ke-Esaan Tuhan. Al Asy'ari berpendapat bahwa Tuhan memiliki sifat-sifat yang nyata dan abadi, namun ia berusaha untuk menjaga dan memelihara antropomorfisme. Tuhan mengetahui karena sifat-Nya Yang Maha Mengetahui, Tuhan berkehendak, karena sifat-Nya yang berkehendak. Hal itu tidak identik dan tidak juga berbeda dengan hakekat-Nya. Kesemuanya itu nyata, walaupun itu nyata, walaupun kita tidak tahu bagaimana semuanya itu bisa terjadi. ${ }^{36}$

Tentang pahala dan siksaan, Al Asy'ari berpendapat bahwa semua itu terletak pada kemutlakan Tuhan. Tuhan bisa menyiksa dan juga memberi pahal kepada siapa saja yang dikehendaki, karena Tuhan berkuasa mutlak. Tindakan manusia semuanya sudah ditentukan Tuhan, apakah itu baik maupun buruk. ${ }^{37}$

Munculnya teologi Asy'ariyah adalah conter aliran Mu'tazilah. Perbedaan keduanya antara lain

Perlama, apabila Mu'tazilah berpendapat bahwa al-Qur'an adalah makhluk, maka Asy'ariyah berpendapat bahwa al-Qur'an bukan diciptakan dan benar-benar merupakan sabda Tuhan.

Kedua, ungkapan-ungkapan yang antropomorfis dalam al-Qur'an. Jika Mu'tazilah mengatakan bahwa Yad Allah (tangan Allah), maka yang dimaksud adalah (rahmat-Nya), pendapat Asy'ari berbeda bahwa Yad Allah (tangan Allah) harus diterima begitu saja, tanpa harus merinci "bagaimana" (bila kaifa).

Ketiga, tentang melihat Tuhan di akhirat. Mu'tazilah mengartikan melihat Tuhan bukan dengan kepala, tetapi dengan mata hati, tetapi Asy'ari mengartikan melihat Tuhan adalah melihat dengan mata kepala. 
Keempat, tentang kebebasan manusia dalam berbuat. Menurut Mu'tazilah menusia bebas berbuat, sedangkan menurut Asy'ari Tuhan telah menciptakan perbuatan itu dan manusia memperolehnya. ${ }^{38}$

Seiring dengan teologi Asy'ariyah, muncul pula teologi Maturidiyah, yang dipelopori oleh Abu Ma'sur al Maturidy (wafit 333 H/945 M) Maturidiyah mengikuti teologi al Asy'ari, tetapi ada perbedaan dalam beberapa hal. Al Maturidy bexpendapat bahwa semua tindakan merupakan kehendak Tuhan, tetapi perbuatanperbuatan dosa tidak muncul sebab ridla Tuhan. ${ }^{39}$ Kemudian perlu juga disebut di sini, yaitu teologi Salafiyah. ${ }^{40}$ Ketiga aliran teologi (Asy'ariyah, Al Maturidiyah dan Salafiyah) itulah yang mengklaim dirinya sebagai golongan ahlu sunnah wal jama'ah.

\section{Metodologi Teologi}

Melihat aliran teologi begitu banyak, maka dalam membahas masalah metode ini dipilih beberapa aliran yang benar-benar menggunakan metode yang berbeda. Di antaranya adalah teologi Mu'tazilah, Asy'ariyah dan Salafiyah.

Pertama metode Mu'tazilah. Menurut sebagian ahli, tokoh-tokoh merupakan pendiri ilmu kalam yang sebenarnya dalam Islam. ${ }^{41}$ Kalam yang dikembangkan Mu'tazilah dalam bentuk apologetik, sebagai pembelaan diri terhadap agama dan kepercayaan Islam.

Aliran kalam ini dibangun di atas kekuatan rasional, ${ }^{42}$ sehingga terkenal dengan aliran rasional dalam Islam. Mereka menempatkan ratio dan akal yang paling tinggi dalam kehidupan beragama. Status akal yang tinggi dalam Mu'tazilah ini minimal mempunyai dua arti yang sangat penting, pertana, bahwa manusia mempunyai kemauan yang besar dengan akal yang dimilikinya, kedua bawa segala perbuatan manusia secara eskatologis tak ada yang sia-sia pada masa apapun. Metode rasional sangat dominan dalam pemikiran tokoh-tokoh Mu'tazilah. ${ }^{43}$

Metode rasional yang sering dipengunakan oleh tokoh Mu'tazilah adalah Qiyas al Ghaib ala al Sahid (menganalogikan yang immateral (Tuhan) terhadap yang nampak (manusia)). Penggunaan metode ini munglin berkaitan erat dengan pandangan Mu'tazilah yang antroprosentis dalam teologinya Menurut Ali Syami 
al Nasyar, metode berpikir ini yang kemudian banyak dipergunakan para teolog Islam adalah orisinil dari kalangan Islam, bukan penganuh logika formal Yunani. ${ }^{44}$

Meskipun metode sangat dominan dalam teologi Mu'tazilah, sebagai teolog Islam, para tokohnya tidak melupakan teks-teks al Qur'an dan al hadits dalam memformulasikan pendapat-pendapatnya. Al Qur'an dan al hadits adalah sumber pokok kepercayaan yang mereka yakini kebenarannya. Hanya saja teks-teks wahyu yang sesuai dengan dan diterima oleh akal, mereka jadikan sebagai pendukung pendapat-pendapat mereka, sedangkan yang tidak sesuai dengan dan diterima akal, mereka tafsirkan secara rasional atau dilewatkan begitu saja. ${ }^{.5}$

Kedua metode Salafiyah. Menurut Ibrahim Madkur yang disebut dengan golongan salaf ialah mereka yang berpegang teguh kepada athar (hadits), lebih mengutamakan riwayat daripada diriwayat dan mengutamakan naqal (wahyu) daripada akal. Mereka menganggap dirinya sebagai ahl al sunnah wa al jama 'ah, karena paham akidah mereka dianggap orisinil dari ajaran Islam yang dibawa Nabi Muhammad SAW sebagaimana yang diterima oleh umat Islam pertama. ${ }^{16}$

Para tokoh Salafiyah dalam teologinya menggunakan metode tekstual yang mengharuskan akal tunduk dibawah naqal. Ibnu Hanbal dan sejumlah tokoh Salafiyah senantiasa mempertahankan metode tekstual dengan mempercayai apa yang disampaikan al Qur'an dan al Hadits tanpa menta'wilkannya dengan dasar persepsi bahwa Tuhan sama sekali berbeda dari segala sesuatu yang terbayang dalam benak orang. Menurut al Ghazali, walaupun Ibnu Hanbal menutup rapat-rapat menta'wilkan teks wahyu dengan akal, namun ia pernah menta'wilkan tiga buah hadits secara rasional. ${ }^{47}$

Ketiga metode Asy'ariyah. Metode yang dipergunakan Abu Musa al Asy'ari memang terbilang unik, ia tidak menafikan metode Mu'tazilah da juga tidak mengabaikan metode Salafiyah. Ia mengambil yang baik dari metode rasional Mu'tazilah dan metode teks al Salafiyah, sehingga ia terkesan menggunakan metode rasional dan naqal secara seimbang, yaitu mempergunakan akal secara maksimal dan memegang naqal dengan kuat, tetapi tidak sekuat Salafiyah dalam menolak akal untuk menjamahnya ${ }^{48}$ Dalam berargumentasi, ia menggunakan tekstual dan rasional. Ia menetapkan obyek-obyek keimanan dengan dalil-dalil tekstual, seperti sifat Tuhan, hari kiamat, sorga neraka dan sebagainya. Tetapi mengani sifat-sifat Tuhan, ia menggunakan dalil-dalil rasional, malah dengan premis-premis yang dipergunakan para filosof. ${ }^{99}$ 


\section{Obyek Teologi}

Dalam membahas obyek teologi ini, minimal ada dua pendapat yang berbeda, walaupun nantinya sebagai analisis tidak menutup kemungkinan akan menemukan konklusi baru tentang obyek teologi.

Pertama obyek teologi menurut teolog klasik. Teolog klasik dari aliran teologi Mu'tazilah dan Asy'ariyah serta teologi salaf. Para teolog klasik mengelompokkan permasalahan teologi kedalam tiga bagian besar, yaitu keesaan zat, keesaan sifat dan keesaan perbuatan Tuhan. ${ }^{50}$ Dari ketiga kelompok tersebut jelas ulama klasik tidak mau keluar dari pembahasan akidah murni. Teolog klasik yang termasuk dalam kategori ini adalah Mu'tazilah dan Asy'ariyah. Sedangkan teologi salaf merumuskan pokok-pokok bahasan teologi kedalam tiga bagian, yaitu keesaan zat dan sifat, keesaan penciptaan dan keesaan ibadah. ${ }^{51}$

Analisis kritis dari obyek teologi di atas adalah bawa benar obyek teologi terbatas kepada ruang lingkup akidah mumi apabila dilihat dari segi institusi, tetapi apabila dilihat dari segi fungsinya, maka obyek tersebut terkesan sempit dan kering. Obyek yang ditawarkan oleh teolog salaf, yang berani memasukkan ibadah dalam pembahasannya, termasuk sudah keluar dari institusi teologi. Karena ibadah sudah termasuk garapan Syari'ah. Dengan dimasukkannya ibadah ke dalam pembahasan teologi, sudah mendekati kepada fungsi teologi.

Kedua obyek teologi yang berdasar kepada institusi teologi dan fungsinya dalam kehidupan masyarakat. Dari sudut pandang ini, obyek teologi mencakup tiga hal, yaitu keesaan akidah, keesaan ibadah dan keesaan mu'amalah. ${ }^{52}$ Dari ketiga obyek teologi ini, peranan dan fungsinya bisa merambah kearah masyarakat. Tetapi kalau tidak masyarakat muslim akan hidup dalam pandangan sekuler. Dalam arti kata, bahwa daya faedah guna dari teologi tidak dapat dirasakan oleh garis horizontal, karena terbatas pada garis vertikal.

\section{E. Pengaruh Teologi}

Dalam pembahasan sub ini, dasar untuk mempermudah pemahaman, maka pengaruh teologi dalam sikap dan kehidupan manusia dapat dibagi menjadi dua kelompok besar, yaitu teologi Qadariyah dan teologi Jabbariyah. 
Paham Qadariyah oleh Harun Nasution disebut sebagai teologi sunnatullah yang mempunyai ciri-ciri antara lain : 1) kedudukan akal yang tinggi, 2) kebebasan manusia dalam kemauan dan perbuatan, 3) kebebesan berpikir hanya diikat oleh ajaran-ajaran dasar dalam al Qur'an dan al Hadits yang sedikit sekali jumlahnya, 4) percaya adanya sunnatullah dan kausitas, 5) mengambil arti metaforis dari wahyu, dan 6) dinamika dalam sikap dan berpikir. ${ }^{53}$ Dengan melihat ciri-ciri di atas dapat ditarik kesimpulan bahwa teologi sunnatullah memakai metode rasional, ilmiah dan filosofis. Dampak dari sini semua adalah membuat manusia lebih dinamis, orientasi dunia tidak dikalahkan oleh orientasi akhirat, sehingga produktivitas umat dalam segala bidang meningkat. Pengaruh teologi sunnatullah dalam bidang perdagangan adalah sangat besar. Seperti Mesir, Suriah, Irak dan Persia menjadi pusat perdagangan rempah-rempah dan sutra di Timur Tengah. ${ }^{54}$

Dalam bidang pertanian, lrak mengahasilkan gandum, beras, kapas dan kurma. Mesir dan Kurasan, tanalr subur Bukhara dan Samafkan, Basrah dan Damsiq menghasilkan kurma, apel, jeruk, anggur, zaitun, delima, semangka dan sebagainya. Sayur-sayuran juga dikembangkan seperti mentimun, terong, bawang dan sebagainya yang bukan hanya untuk memenuhi kebutuhan rumah, tetapi sampai diekspor ke Cina. ${ }^{5 s}$

Dibidang sains juga mengalami kemajuan yang pesat, seperti ilmu kedokteran yang dikembangkan oleh al Razi, Ibnu Sina dan Ibnu Rusy. Ensiklopedi kedokteran diterjemahkan ke dalam bahasa latin dan dipakai di Eropa sampai abad ke 18 Masehi. Ilmu kimia mengalami kemajuan ditangan Jabir dan al Razi. Ilmu astronomi berkembang berkat kecerdikan al Farrazi al Farhani dan sebagainya. Ilmu hewan dikembangkan oleh al Jahiz dan Ibnu Maskawaih yang membawa teori evolusi kurang lebih 700 tahun sebelum Darwin. ${ }^{56}$

Paham Jabbariyah yang disebut juga teologi kehendak Tuhan mutlak mempunyai ciri-ciri antara lain : 1) kedudukan akal yang rendah, 2) ketidakbebasan manusia dalam kemauan dan perbuatan, 3) kebebasan berpikir yang diikat banyak dogma, 4) ketidakpercayaan terhadap sunnatullah dan kausitas, 5) terikat kpeada arti tekstual dari al Qur'an dan al Hadits, 6) statis dalam hidup dan berpikir. ${ }^{57}$

Dengan kedudukan akal yang rendah mengakibatkan pemikiran dalam segala bidang tidak berkembang, bahkan berhenti. Kepercayaan terhadap ketidakbebasan manusia dalam berbuat mengakibatkan munculnya sikap fatalitas dan statis, karena 
semuanya telah ditentukan Tuhan. Hal ini mengakibatkan umat Islam terbelakang, tidak sesuai dengan perkembangan zaman.

Sementara tumbuh subur paham tarekat" yang lebih mementingkan taqamub kepada Allah dengan jalan mengutamakan kehidupan spiritual daripada material, bahkan meninggalkan materi sama sekali. Kehidupan sehari-hari dilalui dengan berorientasi keakhiratan.

Ada satu aspek teologi yang menarik dibicarakan, yaitu meningkatnya kegiatan tarekat, ahli hikmah, tabib dan kyai yang mengobati dan memberi pertolongan spiritual psikologis kepada umatnya. Umat telah banyak merasakan kegelisahan, seperti pengangguran, tidak naik pangkat, koruptor. Untuk mengatasi masalah yang disandangnya, mereka lari kekegiatan spiritual. ${ }^{59}$

Teologi Asy'ariyah yang bersifat teosentris mengakibatkan kuat-kuat dalam berikhtiar (berusaha) dan cepat menyerah kepada takdir, kurang ambisi dinamis dan kurang kreatif. ${ }^{60}$

\section{F. Kesimpulan}

Untuk menggambarkan pengaruh teologi dalam sikap tindakan manusia nampaknya agak sulit, hal ini disebabkan obyek teologi yang hanya benar-benar mengakar kearah vertikalisasi belum kearah horizontalisasi. Apabila pengaruh itu benar-benar berbentuk kegiatan, sikap dan tindakan, maka hal itu lebih cenderung pada kawasan Syari'at.

Walaupun demikian, untuk menggambarkan secara baik dan jelas kita perlu mencermati melalui motivasi yang ditimbulkan oleh teologi. Secara tidak langsung, keyakinam seseorang akan membawa kearah tindakan real. Tipe teologi Qadariyah yang menggunakan metode rasional, ilmiah dan filosofis, secara langsung maupun tidak langsung telah mewarnai sejarah umat Islam. Sejarah mencatat bahwa pada zaman klasik (650-1250 M) umat Islam telah mengalami kemajuan disegala bidang kehidupan.

Kemudian pada zaman pertengahan (1250-1800 M) teologi Islam banyak didominasi oleh aliran Jabbariyah dengan menggunakan metode fasilitas. Akibatnya adalah kehidupan duniawi makin tertinggal dan beralih kepada suburnya kehidupan ukhrawi. Melalui kegiatan tarekat, umat Islam benusaha ingin selalui berdekatan 
dengan Aliah, sementara dunia dianggap hal yang merintangi, sehingga harus dijauhi, bahkan ditinggalkan.

\section{Endnotes}

Syari'ah merupakan aspek amaly yang memuat aturan yang harus dipatuhi oleh seorang muslim dalam kehidupannya, baik dalam hubungannya dengan Tuhan, alam, manusia maupun dengan kehidupan itu sendiri. Lihat M. Zurkani Yahya, Teologi al-Ghazali, Pendekatan Metodologi, Pustaka Pelajar, 1996, Yagyakarta, 1

Munculnya perbincangan masalah akidah menjadi perhelatan dikalangan sarjana Menurut Ibn Hasmin, Shahrastani dan al Baghdady, munculnya akidah disebabkan pengaruh agama Kristen dan para pendeta ke masyarakat Islam. Mereka berpendapat bahwa perbincangan masalah sifat Tuhan dan Qada

Qadar berasal dari kalangan mawali, yaitu tawanan perang yang sudah dibebaskan dan baru masuk Islam, dan agama sebelumnya Majusi, Nasrani, Yahudi dan sebagainya. Menurut Syaikh Mustafa Abd. Al Razak timbulnya perbincangan tentang akidah dalam Islam karena ajaran Islam yang tedapat dalam al-Qur'an, disamping adanya faktor politik, sosial dan budaya. Lihat lebih lanjut Ahmad Daudy, Kuliah Ilmu Kalam, Jakarta, PT. Bulan Bintang, 1997, hal. 18-19.

Q.S. Al asr;3

4 Q.S. Taha; 14, QS. Isra';23

Figh secara singkat menurut Mukhtar Yahya diartikan sebagai sekelompok hukum tentang amal perbuatan manusia yang diambil dari dalil-dalil terperinci. Yang dimaksud dengan amal perbuatan manusia adalah segala amal perbuatan orang mukallaf yang berhubungan dengan bidang ibadah, mu'amalat, pidana dan sebagainya, sedangkan yang dimaksud dengan dalil-dalil yang terperinci adalah satuan dalil-dalil yang masingmasing menunjuk kepada suatu hukum tertentu. Lihat Mukhtar Yahya, Fatchurrahman, Dasar-Dasar Pembinaan Hukum Figh Islam, Bandung, PT. Al Ma'arif, 1995, hal. 15

6 Kahar Mashur, Pokok-Pokok Ulumul Qur'an, Jakarta, Rineka Cipta, 1992, hal. 76 Zurkani Yahya, Op. Cit, hal. 13

Lihat Hasan Syadaly, Ensiklopedi Indonesia, Jilid 6, Jakarta, Ichtiar Baru Van Hoeve, 1984, hal. 3504.

Anton M. Muliono, Kamus Besar Bahasa Indonesia, Jakarta, Balai Pustaka, 1989, hal. 542. 
10 Yang dimaksud Allah dibaca tarhiq adalah dengan bunyi ringan, sehingga menjadi bunyi "Allah" saja. Kaum muslimin membaca tarhiq kata Allah apabila menjadi mudaf Illah yang didahului oleh mudafnya dibaca majnur (kasrah).

11 Kata Allah dibaca tafhim (dibaca berat) dengan bacaan seakan-akan huruf "a" yang berada antara " $L$ " dobel dan huruf " $h$ " berubah menjadi bunyi "o", sehingga menjadi Alloh. Huruf "l" dobel yang dibaca tafhim seolah-olah menjadi bunyi "w", sehingga berbunyi "Awlloh". Kata Allah dibaca tafhim bertujuan untuk menunjukkan bahwa Allah mempunyai nama dan sebutan yang agung yang suci dan terpelihara dari kotoran kafir san shirik.

12 Teologi Natural adalah teologi yang dimulai dengan pengetahuan alamiah manusia Teologi sebagai suatu ilmu berdasar kepada fakta, bahwa kita dapat mengetahui dengan pasti tentang Allah, baik eksistensinya, esensinya maupun aktivitasnya. Lihat Loren Bagus, Kamus Filsafat, Jakarta, PT. Gramedia Pustaka, 1996, hal. 1092

13 Teologi Wahyu, yaitu teologi yang berdasarkan pernyataan-pernyataan wahyu yang datang dari Allah. Fungsinya memperlihatkan bahwa wahyu merupakan suatu faktor historis (teologi fundamentalis), dipihak lain merupakan isi wahyu dan sumber teologis (teologi positif) dan menjabarkan konseptual ilmiah dari wahyu (Lihat ibid, hal. 1093)

i. Teologi Dialektika adalah teologi yang berpandangan bahwa adanya ketidaksanggupan total manusia yang jatah untuk mengetahui Allah dan untuk melakukan apa yang sebenarnya baik. (Lihat Loc. Cit).

Teologi Negatif, yaitu teologi yang mengajarkan bahwa adanya Allah begitu luas melebihi manusia yang terbatas. Tak satupun ciri-cirinya dapat dikenali dalam arti yang senyatanya. (Lihat ibid, hal. 1094).

16. Harusn Nasution, Teologi Islam, Aliran-Aliran Sejarah Analisa Perbandingan, Jakarta. UI Press, 1972, hal. 6

17 Fazlur Rahman, Islam, Terj. Soenaji Saleh, Jakarta, PT Bina Aksara, 1979, hal. 134

is Ibid, hal. 7

10 Ahmad Daudy, Op Cit, hal. 96

Masyhur Amin, Teologi Pembangunan, Yogyakarta, LKPSM NU, 1989, hal. 125

21 Ibid, hal. 126

Ibid, hal. 127

23 Kelompok al Azariqah adalah pengikut Nafi' itn al Azraq yang berpendapat bahwa semua muslimin yang tidak menganut paham khawarij adalah orang kafir. Tidak boleh para pengikutnya shalat berjama'ah bersama dengan yang bukan khawarij. Tidak boleh kawin dengan orang yang bukan khawarij dan boleh menyerbu kelompok yarig bukan khawarij tanpa permaklumat terlebih dahulu. (Lihat Masyhur Amin, Loc. Cit.) 
24 Al Nadjat, yaitu kelompok yang menjadi pengikut Ajdah ibn Amir. Mereka berpendapat bahwa apabila sesecrang keliru dalam berjihad dapat dimaafkan. Agama terdiri dari dua hal, yaitu mengenal Allah dan mengenal Rasul-Nya. (Lihat Loc. Cit)

Kelompok Ibadiyah, yaitu kelompok yang mengikuti Abdullah ibn Ibad al Tamimy. Menurutnya kawin dengan mereka yang bukan khawarij diperbolehkan (Loc.Cit) Ahmad Amin, Duhbal Islam, Singapura, Maktabah Sulaiman Murni, 1995, hal. 282

27 Fazlur Rahman, Op. Cit., hal. 135

Abu Hasan Ali, al Maqalat al Islamiyah wa Ikhtilar al Musallin, Beirut, al Maktabah al Asyriyah, tt, hal. 219

2. Fazlur Rahman, Loc. Cit

3") Ibid, hal. 136

31 W. Mongomey Watt, Pemikiran Teologi dan Falsafah Islam, Tej. Umar Basalin, Jakarta, P-3 M, 1987, hal. 75

32 Ahmad Daudy, Op. Cit, hal. 100

32 W Mongomery Watt. Op. Cit., hal. 86

34 M. Zukani Yahya, Op. Cit, hal. 31

34 la lahir di Basarh dan dibesarkan oleh lingkungan Mu'tazilah, termasuk juga mengikuti teologi Mu'tazilah sampai umur 40 tahun Hal ini disebabkan Abu Musa al Asy'ari pernah berguru seorang tokoh Mu'tazilah bernama Abu Ali al Juba'i (wafat $303 \mathrm{H}$ ). Dia termasuk murid yang cerdas sehingga sering menggantikan gurunya mengajar Setelah berpikiran matang, ia mengalami konversi. Ia meninggalkan paham Mu'tazilah yang telah dianutnya berpuluh-puluh tahun dan berbalik menyerang dengan alat yang dipergunakan aliran itu sendiri dan sekaligus menetapkan paham baru yang dianutnya Paham ini kemudian mendapat pengikut yang banyak, sehingga namanya diabadikan sebagai nama aliran, yaitu aliran Al Asy'ariyah. (Lihat M. Zurkani Yahya, Op Cit, hal. 40).

36 Fazlur Rahman, Op. Cit., hal. 145

37 Ibid, hal. 146

Fazlur Rahman, Op. Cit., hal. 146

Menurut Abu Zahrah, Salafisme diformulasikan baru pada abad keempat hijniyah, tanpa menyebutkan siapa yang melaksanakan hal itu. Hanya saja ia menjelaskan salafisme berasal dari kalangan Hanabilah, yaitu para pengikut Ahmad bin Hanbal (wafat $241 \mathrm{H}$ / $855 \mathrm{M}$ ). baru pada abad ketujuh hijriyah salafisme diformulasikan secara lengkap oleh Ibnu Taimiyah (729 H/1329 M) (Lihat Muhammad Abu Zahrah, Tarikh al Madzhab al Islamiyah. (Mesir, Dar al Fikr al Arabi, tt), hal. 225 
41 Ibrahim Madar, Fi al Falsafah al Islamiyah, (Mesir, Dar al Ma'arif, tt)., hal. 36

42 Harun Nasution, Op. Cit., hal. 38

43 Ahmad Amin, Zuhr al Islam, (Kairo, Muktarah al Nahdah al Misriyah, 1975), hal. 20

44 Ali Syami al Nasyr, Manahij al Bahth ind Mufakkir Islam, (Mesir, Dar al Fikr al Araby, 1997), hal. 110

45 Ibnu Hazm, Al Faishal fi al Mihal wa al Nihal, (Maktabah al Mu'ayyad, 1317 H), hal. 53

th Ibrahim Masdar, Op Cit., hal. 30)

47 Al Ghazali, Ihya' Ulum al Din, Juz II, (Beirut, Dar al Fikr, 1980), hal. 179

48 Ibrahim Masdar, Op. Cit., hal. 47-48

49 Muhammad Abu Zahrah, Ibnu Taimiyah, (Mesir, Dar al Fikr al Araby, tt.), hal. 189

(1) Masykur Amin, Op Cit., hal. 13

s) Ibid, hal. 14

$\because \quad$ Ibid, hal. 16

43. Harun Nasution, Ilmu Rasional, Gerakan dan Pemikiran, (Bandung, Mizan, 1996), hal. 112

st Ibid, hal. 113

« Ibid, hal. 114

in Ibid, hal, 115

‘ Ibid, hal. 116

48 Ibid, hal. 117

‘o Masykur Aminh, Op. Cit., 53

on Ibid, hal. 42 


\section{Bibliography}

Abu Hasan Ali, Maqalat al Islamiyah wa Ikhtilaf al Musallin, Beirut, Al Maktabah, Al Arabiyah, tt.

Ahmad Amin, Duh al Islam, Singapura, Maktabah Sulaiman Muri, 1995

, Zuhr al Islam, Kairo, Maktabah al Nahdah al Misriyah, 1975

Ahmad Daudi, Kuliah Ilmu Kalam, Jakarta, Bulan Bintang, 1997

Ali Syami al Nasyr, Manahij al Bath al Islamiyah, Mesir, Dar al Ma'rifah, t.t.

Anton M. Muliono, Kamus Besar Bahasa Indonesia, Jakarta, Ikhtiar Baru Van Hoeve, 1989

Fazlur Rahman, Islam, Terj. Senoaji Saleh, Jakarta, Bina Aksara, 1979

Al Ghazali, Ihya' Ulum al Din, Beirut, Dar al Fikr, 1980

Harun Nasution, Islam Rasional, Gerakan dan Pemikiran, Bandung, Mizan, 1995

—, Teologi Islam, Sejarah Analisis Perbandingan, Jakarta, Bina Aksara, 1979

Ibrahim Madkur, Fi al Falsafah al Islamiyah, Mesir, Dar al Ma'arif, t.t.

Ibnu Hazm, Al Fisal fi al Mihal wa al Nihal, Maktabah al Mu'ayyad, $1317 \mathrm{H}$.

Kahar Masyhur, Pokok-Pokok Ilmu al Qur'an, Jakarta, Rineka Cipta, 1992

Loren Bagus, Kamus Filsafat, Jakarta, Gramedia Pustaka, 1996

M. Zurkani Jahja, Teologi al Ghazali, Yogyakarta, Pustaka Pelajar, 1996

Mukhtar Yahya, Fatchurrahman, Dasar-Dasar Pokok Hukum Figh Islam, Bandung, PT. Al Ma'arif, 1994

Masyhur Amin, Teologi Pembangunan, Yogyakarta, LKPSM NU, 1989

Muhammad Abu Zahrah, Tarith al Madzhab al Islamiyah, Mesir, dar al Fikr al Araby, t.t.

- Ibnu Taimiyah, Mesir Dar al Fikr, t.t.

W. Mongomery Watt, Pemikiran Teologi dan Filsafat Islam, Terj. Umar Basalim, Jakarta, P3M, 1987 